\title{
Elastisitas Permintaan Rumah Sederhana Tipe 36 di Kota Padang Provinsi Sumatera Barat
}

\author{
Bunga Paramita \\ Fakultas Ekonomi Universitas Maritim Raja Ali Haji, Tanjungpinang, Kepulauan Riau, Indonesia
}

\begin{abstract}
ABSTRAK : Penelitian ini bertujuan untuk menganalisis elastistas permintaan rumah sederhana tipe 36 di Kota Padang Provinsi Sumatera Barat. Sampel yang digunakan dalam penelitian ini berupa data sekunder, sampelnya berjumlah 32 unit observasi. Variabel yang digunakan meliputi harga rumah sederhana tipe 36, jarak perumahan ke CBD, tingkat density (kepadatan) penduduk perkecamatan, jumlah rumah tangga per kecamatan, dan PDRB per kapita. Alat analisis yang digunakan merupakan regresi data panel dengan menggunakan pendekatan OLS (common), variabel boneka (fixed effect) dan random effect. Hasil analisis menunjukkan bahwa metode fixed effect menghasilkan regresi yang terbaik dari 3 (0tiga) pendekatan yang ada dalam data panel, di mana variabel harga rumah sederhana tipe 36 berkorelasi negatif dan signifikan terhadap jumlah rumah sederhana tipe 36 yang diminta di Kota Padang dengan tingkat elastisitas permintaan sebesar 1,56\%, jarak perumahan ke CBD berkorelasi negatif dan signifikan terhadap jumlah rumah sederhana tipe 36 yang diminta di Kota Padang dengan tingkat elastisitas permintaan sebesar $1,73 \%$, Hasil penelitian ini memberikan gambaran bahwa permintaan rumah sederhana di Kota Padang Sumatera Barat elastis terhadap harga rumah sederhana tipe 36 dan jarak perumahan ke CBD.
\end{abstract}

Kata kunci: elastisitas permintaan rumah sederhana tipe 36, faktor ekonomi, fixed effect

\begin{abstract}
This research aims to analyze type 36 house demand elasticity in Padang City, West Sumatera Province. It used secondary data collected from 32 units of sample observation. The variables were 36-type housing price, distance to $C B D$, district density, number of household, and GDP per capita. The instruments of analysis were data panel regression using OLS approach, fixed effect, and random effect. The analysis results show that fixed method gives the best result of regression among the three approaches in the data panel. The variable of house price has a negative and significant correlation with the demand in Padang City with an elasticity level of $1.56 \%$; the distance to CBD has a negative and correlation with demand with an elasticity level of $1.73 \%$. The research results give a picture that the demand for simple houses in Padang city, West Sumatera Province is elastic toward the price of type 36 house, and distance to CBD.
\end{abstract}

Keywords: demand elasticity of simple type 36 house, economic factor, fixed effect

Email Address : bungaparamita1@gmail.com 


\section{Pendahuluan}

Dalam Undang-Undang nomor 4 tahun 1992 tentang perumahan dan pemukiman dinyatakan bahwa rumah merupakan bangunan yang berfungsi sebagai tempat tinggal atau hunian, serta sarana pembinaan keluarga. Rumah tidak dipandang sebagai bentuk fisik menurut standar tertentu (dwelling unit), tetapi merupakan proses interaksi antara bangunan rumah dengan penghuni dalam siklus waktu hidupnya. Pada pasal 5 ayat 1 juga dinyatakan bahwa setiap warga negara mempunyai hak untuk menempati dan atau menikmati dan atau memiliki rumah secara layak dalam lingkungan yang sehat, aman, serasi dan teratur.

Dalam hal pembiayaan perumahan, bisnis properti berkaitan erat dengan suku bunga karena bersifat padat modal, sehingga sangat rentan terhadap peredaran uang dan tingkat suku bunga. Saat bunga KPR turun seiring dengan menurunnya ratarata tertimbang tingkat diskonto (suku bunga)
SBI, dan diikuti dengan KPR yang meningkat akan meningkatkan permintaan rumah atau properti.

Kota Padang merupakan ibukota Provinsi Sumatera Barat, Provinsi dengan etnis Minangkabau, sangat spesifik karena menganut sistem keturunan dari garis ibu. Kegiatan sektor perdagangan menempati urutan kedua setelah sektor keuangan. Sebagai ibukota Provinsi Sumatera Barat, Kota Padang memiliki Pelabuhan Alam Teluk Bayur yang merupakan pintu gerbang kelautan yang menghubungkan Sumatera Barat dengan daerah-daerah lainnya, memberikan dampak yang positif bagi perkembangan Kota Padang. Salah satu sarana pendukung perkembangan Kota Padang lainnya adalah dengan mulai di operasikannya Lapangan Udara dengan sebutan Minangkabau Internasional Airport (MIA) di Ketaping sejak bulan Juli 2005, menjadikan Kota Padang sebagai sentral bisnis di Sumatera Barat.

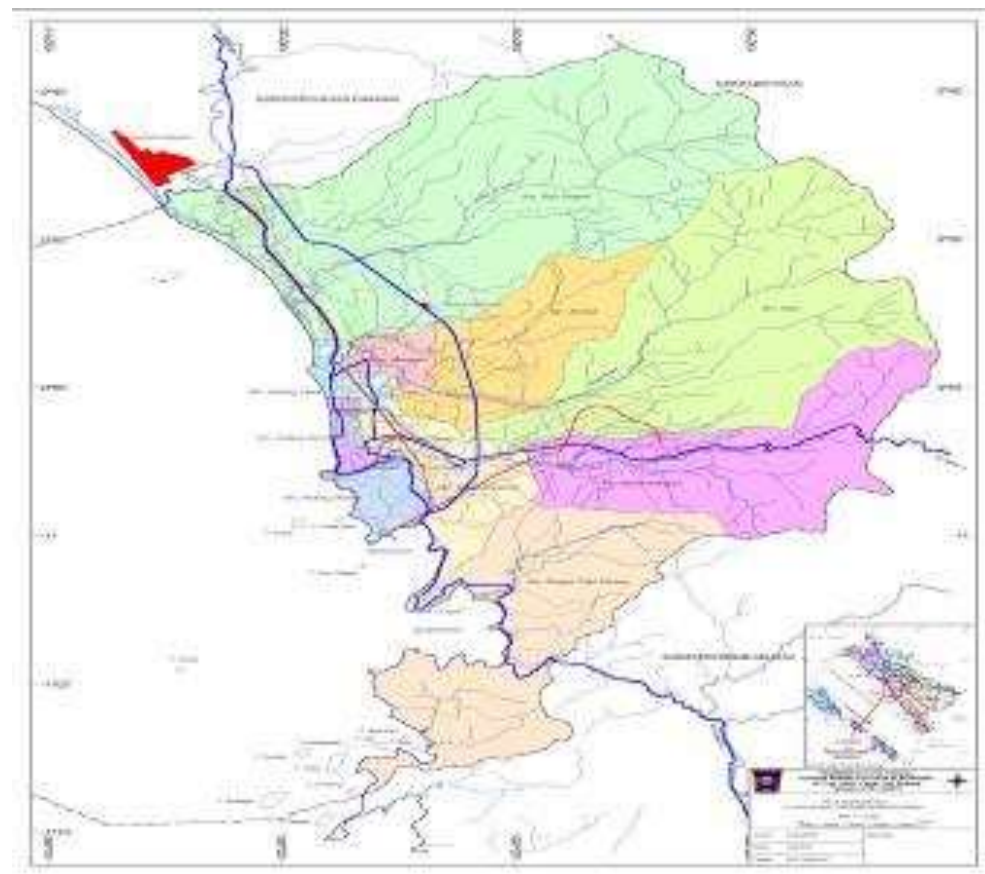

Gambar 1.1

Peta Kota Padang 
Wilayah Kota Padang secara geografis memiliki batasan-batasan sebagai berikut:

1. sebelah Utara berbatasan dengan Kabupaten Padang Pariaman;

2. sebelah Selatan berbatasan dengan Kabupaten Pesisir Selatan;

3. sebelah timur berbatasan dengan Kabupaten Solok;

4. sebelah Barat berbatasan dengan Samudera Indonesia.

Kota Padang dengan luas 694,96 km², memiliki 17 pulau kecil dan mempunyai garis pantai $\pm 68 \mathrm{~km}$, dengan kondisi ini Kota Padang disebut sebagai kota water front city. Secara administrasi terdiri dari 11 kecamatan dan 104 kelurahan. Adapun laju pertumbuhan penduduk pada tahun 2003 ada

sebesar 1,92\%, pada tahun 2004 adalah 2,43\% dan pada tahun 2005 menjadi

$2,44 \%$ dengan demikian kepadatan penduduknya bertambah dari $1.129 \mathrm{jiwa} / \mathrm{km}^{2}$ tahun 2004 menjadi 1.153 jiwa $/ \mathrm{km}^{2}$ tahun 2005. Jumlah penduduk terbesar terdapat di Kecamatan Koto Tangah yakni 148.264 jiwa, tetapi karena wilayahnya paling luas hingga mencapai 33\% dari luas Kota Padang maka kepadatan penduduknya termasuk rendah yaitu sebesar $638 \mathrm{jiwa} / \mathrm{km}^{2}$. Kecamatan terkecil adalah kecamatan Bungus Teluk Kabung dengan jumlah penduduk yaitu 23.197 jiwa tahun 2005, dengan kepadatan $230 \mathrm{jiwa} / \mathrm{km}^{2}$ (BPS, 2005: 58).

Kota Padang dapat dikatakan juga sebagai kota tujuan pendidikan, hal ini terlihat dari banyaknya pendatang dengan tujuan melanjutkan pendidikan ke Kota Padang, Kota Padang memiliki 3 universitas negeri dan 63 universitas swasta (BPS, 2005:100). Jika dibandingkan kepadatan penduduk Kota Padang dengan Kota Yogyakarta yang juga merupakan kota pendidikan, pada tahun 2005

kepadatan penduduk Kota Yogyakarta adalah sebesar $12.938 \mathrm{jiwa} / \mathrm{km}^{2}$ dengan luas daerah $32,50 \mathrm{~km}^{2}$. Hal ini dapat dikatakan bahwa kepadatan penduduk Kota Yogyakarta lebih tinggi dibanding dengan kepadatan penduduk Kota Padang. Untuk laju pertumbuhan penduduk Kota Yogyakarta tahun 2005 adalah sebesar

$12,82 \%$, hal ini menunjukkan bahwa laju pertumbuhan penduduk Yogyakarta lebih tinggi dibandingkan dengan laju pertumbuhan penduduk di Kota Padang.

Kebijakan Pembangunan Kota Padang dituangkan lebih lanjut dalam Rencana Pembangunan Jangka Panjang (RPJP) dan Rencana Pembangunan Jangka Menengah (RPJM). RPJP dan RPJM mempunyai maksud dan tujuan untuk meletakkan landasan yang kuat bagi pembangunan daerah Kota Padang di sebesar 1,92\%, pada tahun 2004 adalah 2,43\% dan pada tahun 2005 menjadi 2,44\% dengan demikian kepadatan penduduknya bertambah dari $1.129 \mathrm{jiwa} / \mathrm{km}^{2}$ tahun 2004 menjadi 1.153 jiwa $/ \mathrm{km}^{2}$ tahun 2005. Jumlah penduduk terbesar terdapat di Kecamatan Koto Tangah yakni 148.264 jiwa, tetapi karena wilayahnya paling luas hingga mencapai 33\% dari luas Kota Padang maka kepadatan penduduknya termasuk rendah yaitu sebesar $638 \mathrm{jiwa} / \mathrm{km}^{2}$. Kecamatan terkecil adalah kecamatan Bungus Teluk Kabung dengan jumlah penduduk yaitu 23.197 jiwa tahun 2005, dengan kepadatan $230 \mathrm{jiwa} / \mathrm{km}^{2}$ (BPS, 2005: 58).

Kota Padang dapat dikatakan juga sebagai kota tujuan pendidikan, hal ini terlihat dari banyaknya pendatang dengan tujuan melanjutkan pendidikan ke Kota Padang, Kota Padang memiliki 3 universitas negeri dan 63 universitas swasta (BPS, 2005:100). Jika dibandingkan kepadatan penduduk Kota Padang dengan Kota Yogyakarta yang juga merupakan kota pendidikan, pada tahun 2005 kepadatan penduduk Kota 
Yogyakarta adalah sebesar 12.938 jiwa/ $/ \mathrm{km}^{2}$ dengan luas daerah $32,50 \mathrm{~km}^{2}$. Hal ini dapat dikatakan bahwa kepadatan penduduk Kota Yogyakarta lebih tinggi dibanding dengan kepadatan penduduk Kota Padang. Untuk laju pertumbuhan penduduk Kota Yogyakarta tahun 2005 adalah sebesar $12,82 \%$, hal ini menunjukkan bahwa laju pertumbuhan penduduk Yogyakarta lebih tinggi dibandingkan dengan laju pertumbuhan penduduk di Kota Padang.

Kebijakan Pembangunan Kota Padang dituangkan lebih lanjut dalam Rencana Pembangunan Jangka Panjang (RPJP) dan Rencana Pembangunan Jangka Menengah (RPJM). RPJP dan RPJM mempunyai maksud dan tujuan untuk meletakkan landasan yang kuat bagi pembangunan daerah Kota Padang di masa datang dengan melakukan reformasi disegala bidang pembangunan.

Visi dari Kota Padang adalah mewujudkan Kota Padang sebagai Pusat perekonomian dan pintu gerbang perdagangan terpenting di Indonesia Bagian Barat, menjadikan Kota Padang sebagai kota tujuan urbanisasi dari daerah-daerah yang ada disekitarnya. Maka sudah dapat dipastikan bahwa kebutuhan akan lahan, perumahan dan pemukiman akan terus mengalami peningkatan.Sehingga harga lahanpunakan semakin meningkat.

Kesanggupan masyarakat untuk memperoleh rumah baik secara cash maupun kredit adalah tidak terlepas dari seberapa besar pendapatan yang diterima oleh masyarakat. Untuk suatu wilayah, pendapatan bagi masing-masing penduduk tercermin dari Produk Domestik Regional Bruto (PDRB) per kapita, yakni PDRB dibagi jumlah penduduk pada pertengahan tahun. Produk Domestik Regional Bruto (PDRB) merupakan data statistik yang merangkum perolehan nilai tambah dari seluruh kegiatan ekonomi di suatu wilayah.

Kebutuhan rumah terus meningkat seiring dengan pertumbuhan jumlah penduduk. Setiap orang butuh rumah, dalam hal ini, banyaknya jumlah unit rumah yang diminta tidak seiring dengan jumlah unit rumah yang ditawarkan di Kota Padang. Berdasarkan hal inilah maka dipandang perlu untuk melakukan kajian terhadap elastisitas jumlah rumah sederhana yang diminta di Kota Padang.

Mengacu pada latar belakang tersebut, tentunya topik ini layak dan menarik untuk di jadikan sebuah penelitian, terlebih lagi penelitian ini menganalisis mengenai elastisitas permintaan rumah sederhana, maka yang menjadi fokus penelitian adalah bagaimana elastisitas permintaan rumah sederhana tipe 36 di Kota Padang Provinsi Sumatera Barat

\section{Tujuan Penelitian}

Tujuan penelitian ini adalah:

1. untuk menganalisis elastisitas jumlah rumah sederhana tipe 36 yang diminta di Kota Padang Provinsi Sumatera Barat, dikaji dari harga rumah sederhana;

2. untuk menganalisis elastisitas jumlah rumah sederhana yang diminta di Kota Padang Provinsi Sumatera Barat, dikaji dari jarak lokasi perumahan ke CBD;

3. untuk menganalisis elastisitas jumlah rumah sederhana tipe 36 yang diminta di Kota Padang Provinsi Sumatera Barat, dikaji dari segi kepadatan penduduk per kecamatan;

4. untuk menganalisis elastisitas jumlah rumah sederhana tipe 36 yang diminta di Kota Padang Provinsi Sumatera Barat, dikaji dari jumlah rumah tangga

\section{Tinjauan Pustaka dan Alat Analisis}

Pelaksanaan pembangunan perumahan di Indonesia pada umumnya dilakukan oleh berbagai pihak. Adapun lingkup pembangunan perumahan menurut Pedoman Pembangunan Perumahan Indonesia sebagai berikut: 
1. pembangunan perumahan dan pemukiman yang dilakukan oleh Perum Perumnas yang penggunaan dan pemilikannya diperuntukkan bagi masyarakat berpenghasilan sedang dan rendah;

2. pembangunan perumahan yang dilakukan oleh perusahaan yang tergabung dalam pengusaha Real Estate Indonesia (REI) yang pada umumnya diperuntukkan bagi golongan masyarakat menengah ke atas;

3. pembangunan perumahan yang dilakukan oleh perusahaan konstruksi swasta yang diperuntukkan bagi golongan masyarakat yang berpenghasilan menengah kebawah melalui KPR BTN;

\section{Karakteristik perumahan}

Rumah mempunyai hal yang spesifik dan unik jika dibandingkan dengan barang lain yang digunakan pada umumnya. Levy (1985 : 191-192) menyebutkan bahwa rumah mempunyai karakteristik spesifik sebagai berikut.

1. Terdapat pada tempat tertentu selama umur bangunannya

2. Secara umum lebih tahan lama. Nilainya dipengaruhi oleh lokasi dan lingkungan sekitarnya.

\section{Lokasi perumahan}

Ekologi perkotaan sebagai suatu dasar teori untuk menjelaskan pola penggunaan lahan untuk pertama kali dikembangkan oleh Burgess, Mckenzie, Wirth \& Dark (lihat Levy, 1985: 64). Dalam ekologi perkotaan ada beberapa teori yang dapat dikelompokkan menjadi 3 (tiga) model.

1. Model Kosentrik Burgess (Burgess Concentric Zone Model)

2. Model Sektoral Homer Hyot (Hyot Sectoral Model)

3. Model Inti Ganda Chancy D. Harris and Edward Ullman (Harris and Ullman Multiple Nuclei Model)

\section{Kebutuhan Rumah Tinggal}

Kebutuhan rumah tinggal semakin meningkat seiring dengan bertambahnya penduduk dan meningkatnya pengetahuan masyarakat tentang rumah yang layak tinggal dan lingkungan yang sehat. Berdasarkan Surat Keputusan Bersama (SKB) 3 (tiga) menteri tentang Pedoman Pembangunan Perumahan dan Pemukiman dengan Lingkungan Hunian yang Berimbang, pada pasal 1 menyatakan bahwa yang dimaksud dengan:

1. rumah sederhana adalah rumah tidak bersusun dengan luas lantai bangunan tidak lebih dari $70 \mathrm{~m}^{2}$, yang di bangun di atas tanah dengan luas kavling $54 \mathrm{~m}^{2}$ sampai dengan $200 \mathrm{~m}^{2}$ dan biaya pembangunan per $\mathrm{m}^{2}$ tidak melebihi dari harga satuan per $\mathrm{m}^{2}$ tertinggi untuk pembangunan rumah dinas tipe $\mathrm{C}$ yang berlaku, yang meliputi rumah sederhana tipe besar, rumah sederhana tipe kecil, rumah sangat sederhana dan kavling siap bangun;

2. rumah sederhana tipe besar adalah rumah sederhana luas lantai bangunan antara $36 \mathrm{~m}^{2}$ sampai dengan $70 \mathrm{~m}^{2}$;

3. rumah sederhana tipe kecil adalah rumah sederhana dengan luas lantai bangunan $21 \mathrm{~m}^{2}$ sampai dengan $36 \mathrm{~m}^{2}$, sekurang-kurangnya memiliki kamar mandi dengan WC dan ruang serba guna;

4. rumah sangat sederhana adalah rumah tidak bersusun dengan luas lantai bangunan $21 \mathrm{~m}^{2}$ sampai dengan $36 \mathrm{~m}^{2}$ dan sekurang-kurangnya memiliki kamar mandi dengan WC dan ruang serba guna dengan biaya pembangunan per $\mathrm{m}^{2}$

\section{Alat Analisis}

Untuk menjawab rumusan masalah digunakan metode analisis kuantitatif dengan alat analisis regresi bentuk log linier. Adapun data yang digunakan dalam penelitian ini merupakan data panel pada periode 2002 2005.

\section{Pemilihan bentuk fungsi model empiris}

Adapun model regresi dalam bentuk log linier dapat ditulis sebagai berikut :

$$
\begin{aligned}
\text { Ln JUT }_{i t}= & \beta 0-\beta 1 \ln \mathrm{HG}_{\mathrm{it}}-\beta 2 \ln \mathrm{J}_{\mathrm{it}}+ \\
& \beta 3 \ln \mathrm{D}_{\mathrm{it}}+\beta 4 \ln \mathrm{JRT}_{\mathrm{it}}+\beta 5 \ln \\
& \text { PDRBit }+\varepsilon_{\mathrm{i}}
\end{aligned}
$$


Keterangan :

a. JUT adalah jumlah unit terjual tiap kecamatan (unit)

b. HG adalah harga rumah per unit tiap kecamatan di Kota Padang (Rp)

c. J adalah jarak lokasi perumahan ke Pusat Kota (CBD) (per km)

d. D adalah kepadatan penduduk tiap kecamatan (per orang) JRT adalah jumlah rumah tangga tiap kecamatan (per $\mathrm{Rt})$

e. PDRB adalah PDRB perkapita tiap kecamatan (juta Rp)

f. $\beta 0$ adalah Intercept

g. $\quad \beta 1 \quad \beta 2 \beta 3 \quad \beta 4 \quad \beta 5$ adalah koefisien regresi variabel bebas

h. i adalah Kecamatan (Koto Tangah, Pauh, Kuranji, Lubuk Begalung, Lubuk Kilangan, Padang Selatan, Padang Utara, Nanggalo)

i. $\mathrm{T}$ adalah Tahun Observasi

j. In adalah Logaritma Natural

k. $\quad \varepsilon$ i adalah variabel pengganggu

\section{Analisis regresi data panel:}

Regresi dengan menggunakan data panel dapat mengatasi permasalahan keterbatasan data. Karena data panel mampu menyediakan data yang lebih banyak, sehingga akan menghasilkan degree of freedom yang lebih besar. Dalam mengestimasi model regresi akan sangat tergantung dari asumsi yang dibuat tentang intersep, koefisien slope dan residualnya, dan ada beberapa kemungkinan yang akan muncul yaitu (Hsiao,Cheng, ibid, pp 9-10).

1. Diasumsikan bahwa intesep dan slope adalah tetap sepanjang waktu dan individu, dan perbedaan intersep dan slope dijelaskan oleh residual.

2. Diasumsikan slope adalah tetap tetapi intersep berbeda antar individu.

3. Diasumsikan slope tetap tetapi intersep berbeda baik antar waktu maupun antar individu.

4. Diasumsikan intersep dan slope berbeda antar individu.

5. Diasumsikan intersep dan slope berbeda antar waktu dan individu.
Untuk mengestimasi model regresi dan proses perhitungan, pada penelitian ini akan digunakan pendekatan OLS (Common), Variabel Boneka (Fixed Effect) dan Random Effect Selanjutnya pendekatan terbaik akan digunakan dalam analisis model regresi dalam bentuk $\log$ linier.

\section{Analisis Ekonomi :}

Analisis ini digunakan untuk memberikan interpretasi ekonomi yang relevan dikaitkan dengan hasil-hasil penelitian sebelumnya dan dampaknya terhadap elastisitas permintaan rumah sederhana tipe 36 .

Tabel 2.1

Variabel Independen dan Arah Parameter

\begin{tabular}{|l|l|c|}
\hline No & \multicolumn{1}{|c|}{ Variabel independen } & $\begin{array}{c}\text { Arah yang } \\
\text { diharapkan }\end{array}$ \\
\hline 1 & Harga rumah sederhana tipe 36 & - \\
\hline & $\begin{array}{l}\text { Jarak lokasi perumahan ke } \\
\text { CBD }\end{array}$ & - \\
\hline & \begin{tabular}{l} 
Tingkat kepadatan penduduk \\
\hline
\end{tabular} & + \\
\hline & Jumlah rumah tangga & + \\
\hline
\end{tabular}

Sumber hasilpenelitian terdahulu (diolah)

\section{Analisis Data}

Metode, sumber dan jenis data

Penelitian ini dilakukan di Kota Padang, Provinsi Sumatera Barat dengan menggunakan data sekunder beberapa kecamatan di Kota Padang Adapun sumber data yang digunakan dalam penelitian ini:

1. Unit rumah sederhana tipe 36 yang terjual, data bersumber dari rekapitulasi tahunan DPD REI cabang Sumatera Barat dengan menggunakan dana BTN.

2. Unit rumah sederhana tipe 36 yang terjual, data bersumber dari rekapitulasi tahunan DPD REI cabang Sumatera Barat dengan menggunakan dana BTN

3. Harga rumah sederhana tipe 36, datanya bersumber dari rekapitulasi tahunan DPD REI cabang Sumatera Barat dengan menggunakan fasilitas dana BTN. 
4. Jarak perumahan ke CBD, bersumber dari dinas pekerjaan umum, bagian prasarana jalan Kota Padang, dinas tata ruang dan bangunan.

5. Tingkat kepadatan penduduk per kecamatan, bersumber dari Padang dalam angka yang diterbitkan oleh BPS Kota Padang.

6. Jumlah rumah tangga per kecamatan, bersumber dari Padang dalam angka yang diterbitkan oleh BPS Kota Padang.

7. PDRB per kapita per kecamatan, datanya bersumber dari Padang dalam angka dan publikasi PDRB Kota Padang yang diterbitkan oleh BPS Kota Padang.

Definisi operasional variabel

Untuk memudahkan dan menyatukan pemahaman dalam pengukur setiap variabel yang diteliti, maka perlu disusun defenisi operasional sebagai berikut.

1. Jumlah rumah yang diminta adalah unit rumah sederhana tipe 36 yang telah terjual dan dibeli oleh konsumen yang dibangun oleh Perum Perumnas dan pengembang swasta lainnya, dengan menggunakan fasilitas Kredit Pemilikan Rumah Bank BTN (KPR BTN) di Kota
Padang, Sumatera Barat.

2. Unit rumah sederhana tipe 36 yang terjual adalah jumlah keseluruhan transaksi dari penjualan rumah sederhana yang diukur dalam satuan unit.

3. Harga rumah sederhana tipe 36 adalah harga pasar yang terjadi dari hasil kesepakan antara penjual dan pembeli yang dinyatakan dalam satuan rupiah.

4. Jarak dari lokasi perumahan ke CBD merupakan suatu indikator yang menunjukkan aksesibilitas (kemudahan) untuk mencapai pusat kota yang dapat dilalui oleh transportasi yang diukur dalam satuan kilometer.

5. Tingkat kepadatan penduduk per kecamatan, merupakan pencerminan dari jumlah penduduk dibagi dengan luas daerah per persatuan jiwa.

6. Jumlah rumah tangga per kecamatan, adalah jumlah penduduk yang telah menikah disuatu wilayah dihitung dari jumlah per kepala keluarga.

7. PDRB per kapita adalah jumlah barang dan jasa yang dihasilkan oleh berbagai unit produksi di tiap kecamatan

Tabel 3.1

Rangkuman Hasil Estimasi Regresi dengan Pendekatan OLS (Common), Variabel Boneka (Fixed effect) dan Random Effect

\begin{tabular}{|c|c|c|c|c|}
\hline \multirow[t]{2}{*}{ No } & \multirow[t]{2}{*}{ Variabel } & \multicolumn{3}{|c|}{ Pendekatan } \\
\hline & & OLS & Fixed Effect & Random Effect \\
\hline 1 & Konstanta & $\begin{array}{l}-149.2080 * \\
(-2,13)\end{array}$ & & $\begin{array}{l}-194.6565 * \\
(-2,49)\end{array}$ \\
\hline 2 & Harga Rumah Sederhana & $\begin{array}{l}-1.373023 * \\
(-2,40)\end{array}$ & $\begin{array}{l}-1.564670^{*} \\
(-2.21)\end{array}$ & $\begin{array}{l}-1.301 \underline{322} * \\
(-2,08)\end{array}$ \\
\hline 3 & Jarak Ke CBD & $\begin{array}{l}-0.645370 \\
(-1,09)\end{array}$ & $\begin{array}{l}-1.730417 * \\
(-2.00)\end{array}$ & $\begin{array}{l}0.013819 \\
(0,03)\end{array}$ \\
\hline 4 & Kepadatan Penduduk & $\begin{array}{l}-0.213545 \\
(-2,11)\end{array}$ & $\begin{array}{l}-1.550030 \\
(-0,38)\end{array}$ & $\begin{array}{l}-0.179152 \\
(-2,19)\end{array}$ \\
\hline 5 & Jumlah RT & $\begin{array}{l}0.860144^{*} \\
(2,55)\end{array}$ & $\begin{array}{l}3.600650 \\
(1,64)\end{array}$ & $\begin{array}{l}0.613022 * \\
(2,25)\end{array}$ \\
\hline 6 & PDRB Per Kapita & $\begin{array}{l}10.57678 \\
(2,23) \\
\end{array}$ & $\begin{array}{l}7.963175 \\
(1,24) \\
\end{array}$ & \begin{tabular}{|l}
$13.34954 *$ \\
$(2,54)$
\end{tabular} \\
\hline & $\mathrm{R}^{2}$ & 0.318726 & 0.656270 & -0.025734 \\
\hline & Adjusted $\mathrm{R}^{2}$ & 0.187712 & 0.439177 & -0.222990 \\
\hline & F-stat & 2.432762 & 9.0668967 & - \\
\hline & Prob. F-stat & 0.061686 & 0.000284 & - \\
\hline & DW-stat & 1.497592 & 2.195952 & 1.297539 \\
\hline & Total Observasi & 32 & 32 & 32 \\
\hline Sumb & $\begin{array}{rrr}\text { an : } & * \text { adalah Signi } \\
& \text { ( ) adalah nila } \\
: & \text { Hasil Perhitungan }\end{array}$ & $\begin{array}{l}\text { ansi (5\%) } \\
\text { tat }\end{array}$ & & \\
\hline
\end{tabular}


1. Pendekatan OLS (Common).

Ada beberapa variabel yang signifikan secara simultan variabel bebastidak mempengaruhi tingkat permintaan rumah sederhana tipe $36 \mathrm{di}$ Kota Padang. Hal ini terlihat dari Fstat < F -tabel, koefisien determinasi yang disesuaikan sangat rendah yang mana hanya $31,87 \%$ variasi tingkat permintaan rumah sederhan tipe 36 dapat dijelaskan oleh model, sisanya diterangkan oleh variabel diluar model. Meskipun rendah koefisien determinasinya, model telah terbebas dari regresi lancung sebagaimana

ditunjukkan oleh indikator DW- stat > $\mathrm{R}^{2} \quad$ (Insukindro dkk, 2001: 199; Gujarati, 2003 : 806-807). pendekatan ini tidak bisa digunakan dalam mengestimasi persamaan regresi data panel .

\section{Pendekatan variabel boneka} (Fixed Effect).

Pendekatan variabel boneka (Fixed Effect) yang digunakan, secara parsial ada beberapa variabel bebas yang signifikan, diasumsikan terdapat perbedaan konstanta antar unit observasi. Secara simultan variabel bebas mempengaruhi tingkat permintaan rumah sederhana tipe 36 yang ditunjukkan dengan signifikansi Fstat > F-tabel dengan probabilitas di bawah $1 \%$. Koefisien determinasi menunjukkan $65,62 \%$ variasi tingkat permintaan rumah sederhana tipe 36 dapat dijelaskan model, sisanya dijelaskan diluar model. Dibandingkan dengan pendekatan OLS (common), koefisien determinasi yang disesuaikan dengan menggunakan pendekatan fixed effect lebih tinggi Pendekatan variabel boneka menghasilkan model yang telah terbebas dari regresi lancung sebagaimana ditunjukkan oleh indikator DW-stat > $\mathrm{R}^{2}$ (Insukindro dkk, 2001: 199; Gujarati, 2005: 806-807). pendekatan ini digunakan mengestimasi persamaan regresi data panel
3. Pendekatan Random Effect.

Menggunakan fungsi model log linier, secara parsial terdapat empat variabel bebas bebas yang signifikan, yaitu konstanta, harga rumah sederhana tipe 36, jumlah rumah tangga perkecamatan.dan PDRB per kapita. Jika kita lihat pada tabel 3.1 di atas, pendekatan ini tidak bisa digunakan, hal ini disebabkan karena adanya korelasi antara residual di dalam metode random effect sehingga tidak dapat digunakan untuk mendapatkan estimator yang efisien.

Berdasarkan hasil estimasi model regresi dengan menggunakan 3 (tiga) pendekatan tersebut, fixed effect mampu mengkoreksi korelasi antar observasi dengan koefisien autokorelasi baik yang muncul karena runtun waktu maupun lintas sektor.

\section{Hasil uji statistik \\ Uji f-statistik :}

Pengujian ini dilakukan untuk melihat apakah ada perbedaan mean. Di mana perbedaan tersebut hanya secara kebetulan ataupun karena faktor lain yang benar-benar berarti atau signifikan, dapat di hitung:

$$
\begin{aligned}
\text { F- tabel } & =\mathrm{F}(\mathrm{k}-1 ; \mathrm{n}-\mathrm{k}) \\
& =\mathrm{F}(\alpha=5 \% ; \mathrm{k}-1 ; \mathrm{n}-\mathrm{k}) \\
& =\mathrm{F}(0,05 ; 4 ; 27) \\
& =2,74
\end{aligned}
$$

Dari hasil regresi diperoleh $\mathrm{F}$ - statistik adalah sebesar 9.068967 berarti dapat dikatakan bahwa F-stat > F - tabel, maka Ho ditolak (signifikan) sehingga dapat disimpulkan bahwa semua variabel bebas secara signifikan mempengaruhi permintaan rumah sederhana.

\section{Uii $\mathbf{t}$ - statistic:}

Keputusan signifikansi ditentukan dengan membandingkan antara t-statistik dari hasil regresi dengan t-tabel, dengan uji satu arah sesuai hipotesis.

Tabel 3.2 Nilai Batas Kritis Uji $t$ - Hasil

\begin{tabular}{|l|l|}
\hline df $(\mathbf{n}-\mathbf{k})$ & $\begin{array}{c}\text { Pengujian satu arah } \boldsymbol{\alpha}= \\
\mathbf{0 , 0 5}\end{array}$ \\
\hline $32-5=27$ & 1.703 \\
\hline
\end{tabular}


$\mathrm{n}=$ Jumlah Observasi

$\mathrm{k}=$ banyaknya koefisien regresi

Sumber : Damodaran Gujarati, Basic Econometrics 4th ed., McGraw-Hill

\section{Interpretasi dan analisis ekonomi}

Analisis ini ditekankan pada kesesuaian tanda yang diharapkan secara teori ataupun berdasarkan pada penelitian empiris sebelumnya, serta makna variabel di dalam model secara ekonomi dan kemungkinan dampaknya terhadap kebijakan. Adapun hasil perhitungan dari model adalah sebagai berikut.

$$
\begin{aligned}
\text { Ln JUTit }= & \beta 0-\beta 1 \ln \mathrm{HG}_{i t}-\beta 2 \ln \mathrm{Jit} \\
& +\beta 3 \ln \mathrm{D}_{\mathrm{it}}+\beta 4 \ln \mathrm{JRT}_{\mathrm{i}} \mathrm{t} \\
& +\beta 5 \ln \text { PDRBit }+\varepsilon_{\mathrm{i}}
\end{aligned}
$$

Tabel 3.6

\section{Hasil Estimasi Regresi dengan Pendekatan} Fixed Effect

\begin{tabular}{|l|l|r|}
\hline No & \multicolumn{1}{|c|}{ Variabel Bebas } & Fixed Effect \\
\hline 1 & $\begin{array}{l}\text { Harga Rumah Sederhana } \\
(\mathrm{HG})\end{array}$ & -1.564670 \\
\hline 2 & Jarak Ke CBD (J) & -1.730417 \\
\hline 3 & Kepadatan Penduduk (D) & -1.550030 \\
\hline 4 & Jumlah RT (JRT) & 3.600650 \\
\hline 5 & PDRB per kapita (PDRB) & 7.963175 \\
\hline & $\mathrm{R}^{2}$ & 0.656270 \\
\hline & Adjusted R $^{2}$ & 0.439177 \\
\hline
\end{tabular}

Sumber : hasil perhitungan

Tabel 3.7

Intercept per kecamatan pada pendekatan Fixed Effect

\begin{tabular}{|l|l|}
\hline \multicolumn{1}{|c|}{ Kecamatan } & Intercept Model Log \\
\hline Koto Tangah & -120.1543 \\
\hline Pauh & -119.2815 \\
\hline Kuranji & -119.4537 \\
\hline Lubuk Begalung & -117.4205 \\
\hline Lubuk Kilangan & -117.6983 \\
\hline Padang Selatan & -115.7190 \\
\hline Padang Utara & -115.9036 \\
\hline Nanggalo & -115.4059 \\
\hline
\end{tabular}

Sumber : Hasil perhitungan

Berdasarkan table 3.7 diatas dari 8 kecamatan yang diestimasi, intercept kedelapan kecamatan di Kota Padang tersebut bertanda negative. Nilai intercept ini digunakan untuk melihat seberapa besar pengaruh variable bebas terhadap permintaan rumah sederhana tipe 36 (unit terjual) di tiaptiap kecamatan (cross section) yang diteliti.

\section{Kesimpulan}

Penelitian ini mengkaji mengenai elastisitas permintaan rumah sederhana di Kota Padang dengan hasil sebagai berikut:

1. Adanya kenaikan harga rumah sederhana tipe 36 sebesar $1 \%$ dapat menurunkan jumlah rumah sederhana tipe 36 yang diminta sebesar (-1.564670) $1,56 \%$ dengan asumsi variabel lain tetap (ceteris paribus). Jadi permintaan rumah sederhana tipe 36 sudah bersifat elastis terhadap harga rumah sederhana tipe 36 di Kota Padang Provinsi Sumatera Barat.

2. Adanya perubahan jarak perumahan ke CBD sebesar $1 \%$ akan menurunkan jumlah rumah sederhana tipe 36 yang diminta sebesar (-1.730417) $1,73 \%$ dengan asumsi variabel lain tetap (ceteris paribus). Jadi permintaan rumah sederhana tipe 36 sudah bersifat elastis terhadap jarak perumahan ke CBD di Kota Padang Provinsi Sumatera Barat

\section{Daftar Pustaka}

American Institute of Real Estate Appraisers, The Appraisal of Real Estate,15th edition, Chicago Illinois, USA.

Badan Pusat Statistik, 2004, Padang Dalam Angka 2004

Badan Pusat Statistik, 2005, Padang Dalam Angka 2005

Badan Pusat Statistik, 2006, Padang Dalam Angka 2006

Badan Pusat Statistik, 2007, Padang Dalam Angka 2007

Badan Pusat Statistik, 2006, Publikasi PDRB Kota Padang 2006, Padang

Badan Pusat Statistik, 2006, Indikator Kesejahteraan Rakyat, Jakarta.

Cheng Hsiao, 2006, Panel Data 
Analysis - Advantages and

Challenges,USA www.google.com

Departemen Permukiman, 2006, Panduan Identifikasi Pemenuhan Kebutuhan Perumahan Untuk Masyarakat Berpenghasilan Rendah, Jakarta

Pemerintah Kota Padang, 2005,

Pedoman Pelaksanaan Pembangunan Rumah Sederhana Sehat Oleh

Pengembang : Peraturan Walikota

Padang No. 15 B tahun 2005

Perum Perumnas, 2006, Pedoman Umum Rumah Sederhana

Sehat. www.google.com

Ras, M; Gameren, E.V; Eggink, E., 2005, The Demand for Housing

Service in Netherlands, www.scp.nl.

Robert Yaffee, 2005, A Primer For Panel Data Analysis, www.neu.edu

Real Estate Indonesia, 2006, Peresmian Rumah Sederhana Sehat, Edisi 02 April

Sukirno, Sadono, 2006, Pengantar Teori Mikroekonomi Edisi ketiga, PT. Raja Grafindo Persada, Jakarta.

Rachmawati, Fenti, 2005, Faktor-faktor yang mempengaruhi Permintaan Rumah Sederhana di Provinsi Jawa Barat, 1996-2003, Tesis S2, Program Pascasarjana Universitas Gadjah Mada, Yogyakarta (Tidak Dipublikasikan).

Yuliana, Heny, 2005, Faktor-faktor yang mempengaruhi transaksi Jual Beli Rumah Sederhana Tipe 36 : Studi Kasus Kota Mataram, NTB, Tesis S2, Program Pasca Sarjana Universitas Gadjah Mada, Yogyakarta (Tidak Dipublikasikan). 